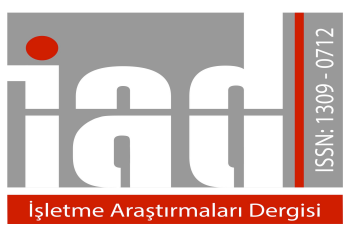

İşletme Araştırmaları Dergisi

Journal of Business Research-Turk

10/3 (2018) 693-709

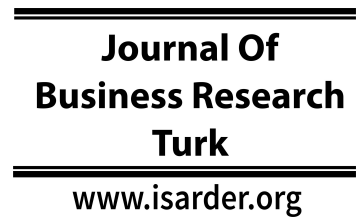

\title{
Macroeconomic Determinants of Non-Performing Loans: Case of Turkey and Saudi Arabia
}

\author{
Ali POLAT \\ Ankara Yıldirım Beyazit University \\ Faculty of Political Science, Department of Economics \\ Ankara, Turkey \\ orcid.org/0000-0001-6041-5003 \\ apolat@hotmail.com
}

\begin{abstract}
Non Performing loans (NPLs) are important variables on a macro scale for the financial stability of the country as well as microscale for banks profitability itself. Since 2008 global crisis, NPLs are monitored worldwide and became systemically important. In this research, by using a data set between 2000-2016, the macroeconomic determinants of NPLs have been investigated for Turkey and Saudi Arabia. By using NPL ratio as the dependent variable and estimating through beta regression analysis, it is found that market capitalization and inflation variables are pozitively related with NPL for Turkey while GDP, inflation, debt, market capitalization and money supply have positively related with NPL for Saudi Arabia and unemployment and transparencey variables are negatively related with NPL for Saudi Arabia. It has been found that the NPL ratios are well explained by some macroeconomic variables. Countries with different macroeconomic conditions have different determinants of NPLs
\end{abstract}

Keywords: Non Performing loans, bad loans, Saudi Arabia, Banking, Financial Crisis, macroeconomic determinants.

\section{INTRODUCTION}

Importance of sound financial institutions and financial system to any developed or developing economy cannot be ignored as economic growth and financial sector development are interrelated with each other. There is a huge strand of literature developed investigating such interconnection (Ang, 2008; De Gregorio \& Guidotti, 1995; Demetriades \& Hussein, 1996). Although financial sector is the primary hub for economic growth, we have to highlight its significance during the high global volatilities where vulnerabilities are at the peak. We refer such times as the crisis times. Most of the time, banking crisis are associated with NPLs in the related literature (Brownbridge, 1998; Demirguc-Kunt \& Detragiache, 1998; González-Hermosillo, 1999; Yang, 2003) and local economic conditions explain the variation in NPL (Keeton \& Morris, 1987). That is the reason that a strand of the NPL literature developed to analyze the association between financial crisis and NPLs and determinants of NPLs. 
In order for a loan to be considered as "non-performing" it should meet certain conditions. The conditions for a loan to be qualified as NPL are that i) it is not earning income and ii) principal payment in full and interest is no longer awaited iii) delinquent principal or interest 90 days or more, or iv) non-payment until the maturity date (Hou \& Dickinson, 2007). ${ }^{\text {i }}$ The financial crisis have a potential to convert performing loans in the banking system to non-performing ones.

The last global financial crisis started in the US not only was exposed vulnerabilities of the banking system of the US but also it had similar effects on other countries all over the world. Gulf Cooperative Council countries (GCC) have been affected by the crises to varying degrees. Mashal (2012) classifies Arab countries into three groups and the first is GCC characterized by open financial systems. They trade with other countries freely and they have a close connection with the global financial system and global markets. These connections were the main channels for the extension of the global crisis to their economies. The other two groups of Arab countries were not affected by the crisis as much as GCC countries did.

Saudi Arabia is among the first group and a local power in the region as well as it is a global power. As a GCC country, Saudi Arabia has witnessed a boom in its economy during 2003-2008, preceding the crisis, as a result of increases in oil revenues and foreign capital inflows. As Mashal (2012) indicates, in 2009, NPLs increased sharply and credit stagnated because of the 2008 crisis. Such relation shows us the importance of the macroeconomic conditions to the overall economy, particularly to the financial system and banking sector.

2008 financial crisis emphasized the importance of linking the macroeconomic environment to the health of the banking system (Espinoza \& Prasad, 2010). Financial crisis cause falling asset prices and it results in borrower defaults through the financial system (von Peter, 2009). Therefore, a banking distress, characterized by NPLs is going to deteriorate the bank assets (Caprio \& Klingebiel, 2002). Increasing interest rates or deteriorating economic conditions lead to increased credit risk. Such increase in credit risk cause deterioration in banks' balance sheet that can lead to tightened credit conditions through a feedback channel into the economy (Espinoza \& Prasad, 2010). The degree of such reciprocal dependence may slow down the flow of funds in financial system, mainly banking sector.

The banks are multichannel financial service providers. One of their main function is to collect the deposit and distribute loans. However, the aggressive push of the banks to increase their client bases to escalate their gains has been replaced by losses in turbulent market conditions. As Tracey (2011) quotes, "the cost of financial intermediation has increased as evidenced by an increase in the cost resulting from higher capital costs and loan losses."

Understanding the importance of NPL for the growth of the country or for the banking sector to function properly together with the risks associated with, it is essential to analyze the causes of the NPLs for the countries. The aim of this paper is to analyze the main macroeconomic determinants of banks' NPL in Turkey and Saudi Arabia over the period 2000- 2016. The initial assumption here is that two countries that their economic cycles are different due to their macroeconomic conditions including but not limited to being oil producer/exporter for Saudi Arabia and oil consumer/importer for Turkey can affect their NPL determinants differently. Ali and Daly (2010) found in their 


\section{A. Polat $10 / 3(2018) 693-709$}

cross-country study that the macroeconomic determinants of credit risk differentiate means that corresponding macroeconomic variable sets display dissimilar default rates for the two separate countries. That result signifies that the changes in macroeconomic variables may have different adverse or favoring impacts from one country to another.

This research will be in 5 sections. After the introduction, there will be a literature review. Section three will provide data and empirical methodology. Section four will have empirical results and related discussion while the last section concludes the research.

\section{LITERATURE REVIEW}

There is an extensive literature regarding macroeconomic performance and bank loans in general. The widespread research on NPLs both in samples used and methods implemented to understand the macro and micro determinants of the NPLs and their effects on the relevant economies employ firm-specific and/or macroeconomic variables as systemic shocks can derive from both firm-specific factors and from macroeconomic imbalances (systemic shocks) (Espinoza \& Prasad, 2010). This research concentrates only on the strand of the literature of NPLs related with determinants of NPLs to capture the analyzed independent variables at macroeconomic level.

Baum, Caglayan Ozkan (2002) investigated the macroeconomic uncertainty and bank lending connection by using U.S bank-level data. They found that macroeconomic uncertainty will narrow cross-sectional distribution of loan-to-asset ratios of the banks.

Calza, Gartner and Sousa (2003) identified in their study a cointegration relationship linking real loans, GDP and interest rates for the loans to the private sector in the euro area by using Johansen methodology. The findings signify that real loans and GDP are positively related in the long-run and negatively related to real short-term and long-term interest rates.

Ranjan and Dhal (2003) explored if terms of credit, bank size and macroeconomic shocks influence NPLs in Indian public sector banks. The empirical finding of panel regression suggest that positive conditions lead to lowering of NPL. Babouček and Jančar (2005) analyzed the Czech banking between 1993-2006 and found a positive correlation of NPLs with the unemployment rate and consumer price inflation. The study of IMF (2006) for Spain shows that the exchange rate, unemployment, asset and house prices can also be particularly important.

Hou (2007) applied threshold regression for bank statistics from 1998 to 2005 for some selected countries. The bank level investigation of the research found that NPL level reduces banks' aspiration to lending while different countries have different threshold locations for their aspiration to lending.

Masood and Aktan (2009) investigated NPL in large state-owned commercial banks over the period 1999-2001 and 1996-1998 for Turkey and Pakistan respectively. They applied a questionnaire to credit managers and found that NPL in Turkey is influenced by poor credit risk assessment, loans to insiders and external government.

That paper, in a sense, concentrates on subjective dimensions of NPL determinants rather than quantitative macroeconomic variables. Omar Masood, Bellalah, Mansour and Teulon (2010) also investigated if personal interest and political corruption are influencing factors of the credit managers decision making. Although 
these papers are not related to macroeconomic determinants it is a part of NPL literature regarding Turkey and included in our literature review in that sense. Moreover, this strand of the NPL literature exhibit that the reasons of NPL can be social, institutional and relational factors leading us to the crony capitalism.

Khemraj and Pasha (2009) analyzed Guyanese banking sector by employing a panel dataset to ascertain the determinants of NPL. They found that real effective exchange rate has a positive impact on NPL while GDP growth is inversely related to NPLs.

Espinoza and Prasad (2010) estimated a dynamic panel data over 80 banks for the years 1995 to 2008 in the GCC region. They find that economic growth lowers when the NPL ratio worsens. The results defend the view that both macro-factors and bankspecific characteristics determine the level of NPL. The research also evidence that there is an inverse relationship between real GDP (non-oil) and NPLs.

While Karabulut and Bilgin (2011) analyze the relationship between deposit insurance and NPL relation for Turkey and claims that unlimited deposit insurance causes an increase in NPL in addition to other several factors. Yücememiş and Sözer (2011) propose a model approach regarding the management of NPL and refer to a stock problem of NPL.

Bofondi and Ropele (2011) found for Italian banks that new bad loans (NBL) arising from the household lending alter inversely with the real GDP growth rates and house prices. NBL also varies with the short-term nominal interest rate and the unemployment rate directly. NBL ratio, for the firms, increases with the ratio of net interest expenses to gross operation profits and unemployment rate. NBL also diminishes when the consumption of durables increases.

Louzis, Vouldis and Metaxas (2012) examined the determinants of NPL in the Greek banking sector for each separate loan category. Their findings confirm that NPLs can be clarified in the banking system of Greece by macroeconomic variables, namely interest rates, unemployment, public debt and GDP.

Zeng (2012) report on a utility function and model by using optimal control theory that the equilibrium value of the bank NPLs in China depended on microeconomic factors but influenced by macroeconomic factors.

Mileris (2012) has validated that NPLs in banks highly builds upon macroeconomic changes in a country. The research investigates 22 EU countries for 3 years by employing different techniques from clustering analysis to factor analysis, multiple regression, and polynomial regression. The research confirms that the NPLs ratio highly depends on macroeconomic changes in a country.

Siddiqui, Malik and Shah (2012) investigated the relationship between interest rate volatility on NPL for Pakistan for the period 1996Q4 to 2011Q3 through GARCH. NPL in their research is effected by the interest rate volatility but other macroeconomic variables are suggested to be studied.

Saba, Kouser and Azeem (2012) analyzed the case of US Banking sector for the years from 1985 to 2010 and found that real GDP per capita, inflation and total loans have a significant impact on the dependent variable. 
Ahmad (2013) controlled corruption as a determinant of NPL both at economy and institution level for Pakistan over the period of 2001 to 2010 by OLS and found no vital association of information sharing and corruption with NPL.

Murumba (2013) look at NPL and real GDP relation for Nigeria from 1995 to 2009 and found by applying time series analysis that there is a significant and positive relationship between real GDP and NPLs in Nigerian banking industry.

Badar and Javid (2013) studied long and short-run dynamics of NPLs and macroeconomic variables for Pakistan from January 2002 to December 2011. They employed Johansen and Juselius multivariate cointegration and found a long run relationship between NPL and inflation, exchange rate, interest rate, GDP and money supply. They further investigate if there is any causality and found that inflation and exchange rate Granger caused NPLs.

Klein (2013) studies Central, Eastern and South-Eastern Europe (CESEE) countries for the period of 1998-2001 to investigate the NPL determinants. It is found in the research that main macroeconomic variables such as GDP growth, unemployment and inflation were found to respond to macroeconomic conditions. The analysis also revealed that there are strong feedback effects from the banking system to the real economy.

Messai and Jouini (2013) investigated tree countries, namely Italy, Greece and Spain for the period of 2004-2008 for a sample of 85 banks. By employing panel data regression they found that NPL varies negatively with the growth rate of GDP and positively with the unemployment rate and the real interest rate.

Warue (2013) investigated NPL and effects of bank-specific and macroeconomic factors on the NPLs. It was found that bank-specific factors contribute to NPLs performance more than macroeconomic factors.

Ćurak, Pepur and Poposki (2013) tried to understand the factors of NPL for Southeastern European banks for the period from 2003 to 2010 by using GMM estimator for dynamic panel models. They found that lower economic growth, higher inflation rate and higher interest rate are associated with higher NPL.

Jakubik and Reininger (2013) analyzed CESEE countries and confirm that the main driver of a country's development, economic growth, is inversely correlated with NPL as well as the stock index.

Škarica (2014) analyses NPL in selected European emerging markets on quarterly data between 2007 and 2012. Their findings suggest that the primary cause of high NPL levels is the economic slowdown due to significant and large coefficients on GDP, unemployment and the inflation rate.

Şahbaz and İnkaya (2014) investigated NPLs and their relation with real GDP, total private consumption expenditures and private fixed capital expenditures for Turkey. Granger causality test and VAR method for 1998Q2-2012Q3 and cointegration analysis indicated a long-term relationship between NPLs and the macroeconomic variables while Granger causality test shows that the relationships are bi-directional.

Makri, Tsagkanos and Bellas (2014) study NPL for Eurozone's banking system for the period of 2000 to 2008. They found strong correlations between NPLs and 
various macroeconomic (public debt, unemployment, annual percentage growth rate of gross domestic products) and bank-specific factors.

Abid, Ouertani and Zouari-Ghorbel (2014) estimated NPLs for Tunisia for the years over 2003-2012 for 26 Tunisian banks. Although they attribute GDP, inflation and interest rates as the significant macro determinants of NPLs for Tunisia they also emphasize bad management quality of the banks as determining factors of NPLs.

Beck, Jakubik and Piloiu (2015) used a novel panel data set and study 75 countries covering a decade. Their dynamic panel estimates found a significant effect of real GDP, share prices, the exchange rate and the lending interest rate on NPL ratios.

Ghosh (2015) examined NPL for 50 US states and the District of Columbia for 1984-2013. Implementing fixed effects and dynamic GMM estimations, it was found that real GDP and personal income growth rates and changes in state housing price index reduce NPLs. Inflation, state unemployment rates and US public debt significantly increase NPLs.

Tanasković and Jandrić (2015) investigated NPL determinants for some selected CEEC and SEE countries for the period of 2006-2013. They found a negative relationship between increases in GDP and rise of the NPL ratio. Foreign currency loans ratio and level of exchange rate are positively related with the NPL ratio.

Vatansever and Hepşen (2015) investigated NPL and determining macroeconomic and bank-level indicators from January 2007 to March 2013 for Turkey. They found that industrial production index, Istanbul Stock Exchange 100 Index negatively affect NPL ratio while the unemployment rate has a positive effect on NPL.

İslamoğlu (2015) investigated on the quarterly basis from 2002 to 2013 the NPLs and macroeconomic variables for the banks in BIST (Borsa Istanbul). The findings confirm that macroeconomic variables employed can be used to explain the NPLs.

Yağcilar and Demir (2015) analyzed 26 commercial banks for 42 periods between 2002Q4 and 2013Q1 in Turkey. Their results suggest that growth, interest rates, capital adequacy ratio are in a positive relation with NPLs.

Abdioğlu and Aytekin (2016) examined the years between 2002 and 2014 for Turkish deposit banks. System-GMM and Difference GMM results showed that lagged value of NPLs, net interest margin, capital adequacy and solvency ratio have negative effects on NPLs while interest applied to loans has positive effects on NPLs.

Dimitrios, Helen and Mike (2016) tried to identify the main determinants of NPL in the euro-area banking system for the period 1990Q1 to 2015Q2 using GMM estimation. In addition to already used explanatory variables, they added income tax and output gap for the first time and found the variables to be significant.

Us (2016) analyzed Turkish Banking System and NPLs by also adding a dummy regarding global financial crisis for 2008. He found that NPLs are mostly shaped by bank-specific factors before the crisis, whereas they have a reduced effect after the global crisis, an indication of the global financial conditions.

Beaton and Myrvoda (2016) investigates NPLs in the Eastern Caribbean Currency Union (ECCU) countries and confirm that bank asset quality can be attributed to both macroeconomic and bank-specific factors. 
A current study of Miyajima (2017) approaches the topic from a different angle. In the research, determinants of bank-level credit growth are investigated by applying a panel approach to data spanning over 2000-2015. The results suggest that strong bank balance sheet conditions, economic activity, and oil prices support bank lending.

NPLs are still a center of attraction due to its unambiguous nature of the determining factors and country-specific circumstances. For instance, a recent study of Saif-Alyousfi, Saha and Md-Rus (2018) investigates the oil and gas prices shocks on NPL for Qatar over the period 2000-2016. They found that such variables do not have direct effect, they have indirect effects through country-specific macroeconomic and institutional factors. Baldini ve Causi (2018) investigates the dynamics of Loans and Bad Loans in the Italian non-financial sector for 1998:4 to 2014:4. Their conclusions are that new bad loan entry rate cause loan variations when structural economic factors are removed and there is a negative relation between GDP variation and bad loan flows.

\section{DATA AND EMPIRICAL METHODOLOGY}

\subsection{Data}

Our dependent variable is NPLs ratio and independent variables are some macroeconomic indicators which were given in detail in Table 1. Although it is theoretically possible NPLs to be zero, the values in our sample are $0>y<1$ meaning that there is no year in that NPLs ratio of one of the countries has 0 percent NPLs value. Such a nuance is fundamental in our analysis as the beta regression estimation only allows if the dependent variable hold this condition for the estimation to be consistent. (Stata, 2015)

NPLs ratio is the NPLs divided by the total value of the loan portfolio in the banking sector for a specific year. NPLs data and other variables are not the data that are collected on bank level and aggregated later on. Rather, they are the annually available data collected from the related sources. Therefore it is not possible to differentiate if there are any variation between banks (Islamic vs conventional or small, medium or big banks or private or public etc.)

Table 1: Variables and Data Sources

\begin{tabular}{ll}
\hline \multicolumn{1}{c}{ Variable } & \multicolumn{1}{c}{ Source } \\
\hline Non-Performing Loans, (\% ratio) & World Bank, World Development Indicators \\
GDP growth (annual \%) & World Bank, World Development Indicators \\
Consumer Prices (annual \%) & World Bank, World Development Indicators \\
Unemployment (\% of total labor force) & International Labor Organization, ILOSTAT database \\
Exchange Rate (national currency per USD) & OECD National Accounts Statistics \\
Debt (\% of GDP) & International Monetary Fund \\
Market capitalization (\% of GDP) & World Bank, World Development Indicators, \\
& World Fed of Exc. Db. \\
Corruption Index & Transparency International \\
M3 Money Supply & SAMA Annual Statistics 2016, 2010=100 and OECD \\
Oil Price & U.S. Energy Information Administration \\
Crisis & Dummy =1 for crisis years \\
\hline
\end{tabular}

Dependent and independent variables have the 17 cases except for two variables (market capitalization and corruption) where some cases for Saudi Arabia are missing due to unavailability of data.

Some macroeconomic indicators like GDP growth, Consumer Prices, Unemployment, Exchange Rate Market Capitalization and M3 Money Supply are used 
as they reflect the general state of the economy. As it appears in the literature, the above-given variables are closely related to borrower's capacity to meet their debt obligations.

Debt to GDP ratio, as indicated in our analysis, is also an important indicator in understanding the relation between NPLs and debt. Market capitalization, an indicator which is also known as market value, is "the share price $\mathrm{X}$ the number of shares outstanding for listed domestic companies".

Corruption index is a control variable to see if the institutional dimension has any relation with NPLs. In addition to above, again, two more dummies are added to the analysis to see if there is any effect of oil price or crises on NPLs ratio.

\subsection{Empirical methodology}

Ordinary Least Square (OLS) modeling has a problem if the dependent variable in a regression model is a proportion or percentage. The first problem is that the model can predict values below 0 or above 1 that are not possible as the real data, the ratio, is between 0 and 1 . The second problem is that the relationship is not linear but sigmoidal, a flattened $\mathrm{S}$ shape, linear in the middle but flattened on the ends.

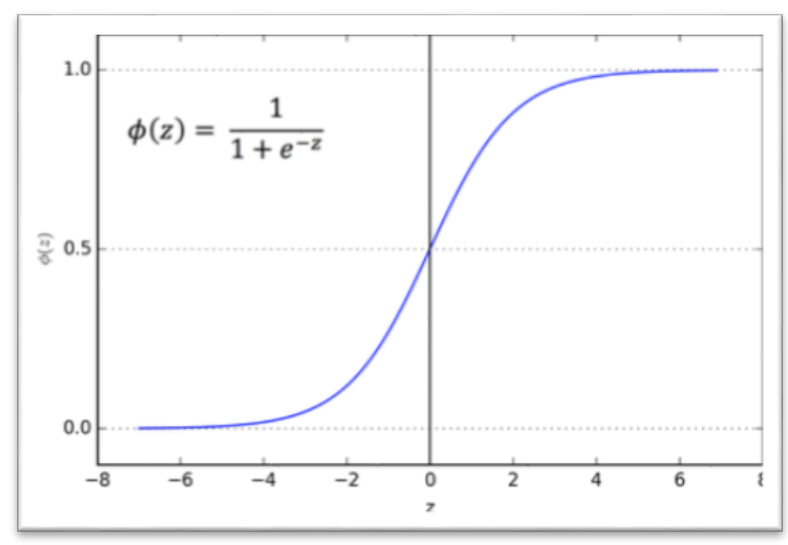

\section{Figure 1: Sigmodial (Beta) Distribution}

In case of the dependent variable as rate or proportion, there are a variety of methods for modeling. If the dependent variable is greater than 0 and less than 1 , beta regression is a widely used technique (Stata, 2015). Beta regression models were first proposed by Ferrari and Cribari-Neto (2004) and extended by Smithson and Verkuilen (2006).

The model specifies the mean of dependent variable $y$, denoted as $\mu_{\mathrm{x}}$, conditional on independent variables $x$ since $y$ is in $(0,1) \mu_{\mathrm{x}}$ must also be in $(0,1)$. In order to restrict the linear combinations of covariates to $(0,1)$ a link function for the conditional mean denoted as $\mathrm{g}($.) is used (Stata, 2015).

The coefficients of beta regression do not allow for determining the magnitude of the effects. Interpretable effect sizes for the covariates can be obtained by margins in Stata. Rather than policy implementation, this research focus on the direction of the significant covariates. Therefore the results are reported as it is.

The null hypothesis $\mathrm{H}_{0}: \beta=0$, means that there is no statistically significant relationship between dependent variable (NPL ratio) and other independent variables. 
The alternative hypothesis is $\mathrm{H}_{1}: \beta \neq 0$ means that there is a statistically significant relationship between dependent variable (NPLs ratio) and others independent variables.

Our model consists of two different single regression equations for each country.

$$
\begin{gathered}
\mathbf{N P L}_{\mathbf{K S A}}=\beta_{0}+\beta_{1} g d p+\beta_{2} \text { cpi }+\beta_{3} \text { unemploy }+\beta_{4} f x+\beta_{5} \text { debt }+\beta_{6} \text { marketcap }+\beta_{7} \text { corrupt } \\
+\beta_{8} m 3+\beta_{9} \text { oilprice }+\beta_{10} \text { crisis }+\varepsilon(1) \\
\mathbf{N P L}_{\mathbf{T R}}=\beta_{0}+\beta_{1} g d p+\beta_{2} \text { cpi }+\beta_{3} \text { unemploy }+\beta_{4} f x+\beta_{5} \text { debt }+\beta_{6} \text { marketcap }+\beta_{7} \text { corrupt } \\
+\beta_{8} m 3+\beta_{9} \text { oilprice }+\beta_{10} \text { crisis }+\varepsilon(2)
\end{gathered}
$$

Beta regression implements maximum likelihood estimators and by default it works with the logit link (Dorta, 2016) which is shown in equation (1) and (2).

$$
\begin{gathered}
\ln \left[\mu_{\mathrm{x}} /\left(1-\mu_{\mathrm{x}}\right)\right]=\mathrm{x} \beta \\
\mu_{\mathrm{x}}=\exp (\mathrm{x} \beta) /(1+\exp (\mathrm{x} B))
\end{gathered}
$$

Although the default link function is logit, there are probit, cloglog and loglog functions available. In order to decide about the model selection a post-estimation test which includes the Akaike information criterion (AIC) and the Bayesian information criterion (BIC) is used. As these measures are also appropriate for maximum likelihood models and beta regression model also computes maximum likelihood estimators, there will be no model selection problem in our estimations by choosing the models with smaller values of an information criterion.

\section{EMPIRICAL RESULTS}

As mentioned in methodology part, there are two regression models separately run for each country. Using a pooled regression, i.e. combining the data for both countries and running only one regression equation, could be a method to implement as long as there is no need to see the country-specific differences as the determinant factors of NPLs ratio.

For Saudi Arabia, we run the beta regression for all of the link functions namely logit, probit, cloglog and loglog. Than we estimated their AIC and BIC criterion as shown below for Saudi Arabia.

Table 2: AIC and BIC Values for Models (KSA)

\begin{tabular}{lcrr}
\hline \multicolumn{1}{c}{ Model } & Df & \multicolumn{1}{c}{ AIC } & \multicolumn{1}{c}{ BIC } \\
\hline Blogit1 & 2 & -3.2 & -3.2 \\
Bprobit1 & 8 & -566 & -565.70 \\
Bcloglog1 & 3 & -3.49 & -3.49 \\
Bloglog1 & 7 & -288 & -287 \\
\hline
\end{tabular}

From the AIC and BIC values, it appears that logit link function is the appropriate selection for the model. (The $1^{\text {st }}$ column) Table 3 shows the regression results for each model run for KSA. 
A. Polat $10 / 3(2018) 693-709$

Table 3: Beta Regression Models for KSA

\begin{tabular}{|c|c|c|c|c|}
\hline NPLs, $\%$ ratio & $\begin{array}{c}\text { (1) logit } \\
\text { NPLs, \% ratio }\end{array}$ & $\begin{array}{c}\text { (2) probit } \\
\text { NPLs, \% ratio }\end{array}$ & $\begin{array}{l}\text { (3) cloglog } \\
\text { NPLs, \% ratio }\end{array}$ & $\begin{array}{c}\text { (4) } \log \log \\
\text { NPLs, \% ratio }\end{array}$ \\
\hline GDP growth (annual \%) & $\begin{array}{l}0.326^{* * *} \\
(0.00)\end{array}$ & $\begin{array}{l}0.144^{* * *} \\
(0.00)\end{array}$ & $\begin{array}{l}0.319^{* * *} \\
(0.00)\end{array}$ & $\begin{array}{l}0.096^{* * *} \\
(0.00)\end{array}$ \\
\hline Inflation, CPI (annual \%) & $\begin{array}{c}\mathbf{0 . 0 6 6}^{* * *} \\
(0.00)\end{array}$ & $\begin{array}{c}0.031^{* * *} \\
(0.00)\end{array}$ & $\begin{array}{c}0.064^{* * *} \\
(0.00)\end{array}$ & $\begin{array}{c}0.022^{* * *} \\
(0.00)\end{array}$ \\
\hline $\begin{array}{l}\text { Unemployment, }(\% \text { of labor } \\
\text { force })\end{array}$ & $-366.958^{* * *}$ & $-162.653^{* * *}$ & $-359.742^{* * *}$ & $-108.468^{* * *}$ \\
\hline $\begin{array}{l}\text { Exchange Rates 1USD to } \\
\text { LCU }\end{array}$ & 0.000 & 0.000 & 0.000 & 0.000 \\
\hline Debt $\%$ of GDP & $\begin{array}{l}0.012^{* * *} \\
(0.00)\end{array}$ & $\begin{array}{l}0.005^{* * *} \\
(0.00)\end{array}$ & $\begin{array}{l}0.012^{* * *} \\
(0.00)\end{array}$ & $\begin{array}{l}0.004^{* * *} \\
(0.00)\end{array}$ \\
\hline Market CAP (\% of GDP) & $\begin{array}{c}0.069^{* * * *} \\
(0.00)\end{array}$ & $\begin{array}{l}0.030^{* * *} \\
(0.00)\end{array}$ & $\begin{array}{l}0.068^{* * *} \\
(0.00)\end{array}$ & $\begin{array}{c}0.020^{* * *} \\
(0.00)\end{array}$ \\
\hline Transparency Int. CPI Index & $\begin{array}{c}-0.191^{* * * *} \\
(0.00)\end{array}$ & $\begin{array}{c}-0.085^{* * *} \\
(0.00)\end{array}$ & $\begin{array}{c}-0.187^{* * *} \\
(0.00)\end{array}$ & $\begin{array}{c}-0.057^{* * *} \\
(0.00)\end{array}$ \\
\hline M3 Money Supply $2010=100$ & $\begin{array}{l}0.027^{* * *} \\
(0.00)\end{array}$ & $\begin{array}{l}0.012^{* * *} \\
(0.00)\end{array}$ & $\begin{array}{l}0.026^{* * *} \\
(0.00)\end{array}$ & $\begin{array}{l}0.008^{* * *} \\
(0.00)\end{array}$ \\
\hline $\begin{array}{l}\text { Oil (EU Brent Spot FOB } \\
\text { USD) Price }\end{array}$ & 0.000 & 0.000 & 0.000 & 0.000 \\
\hline & $()$. & $()$. & $()$. & $()$. \\
\hline $\begin{array}{l}\text { Dummy for crises of } 2001 \\
\text { and } 2008\end{array}$ & 0.000 & 0.000 & (.) & (.) \\
\hline constant & $\begin{array}{c}16.082^{* * * *} \\
(0.00)\end{array}$ & $\begin{array}{l}6.799^{* * *} \\
(0.00)\end{array}$ & $\begin{array}{l}15.679^{* * * *} \\
(0.00)\end{array}$ & $\begin{array}{l}4.539^{* * *} \\
(0.00)\end{array}$ \\
\hline constant & $\begin{array}{l}48.950 \\
(.)\end{array}$ & $\begin{array}{l}35.490^{* * *} \\
(0.01)\end{array}$ & $\begin{array}{l}48.951^{* * *} \\
(0.00)\end{array}$ & $\begin{array}{c}34.321 \\
(.)\end{array}$ \\
\hline $\begin{array}{l}\mathrm{BIC} \\
\mathrm{N} \\
11\end{array}$ & $\begin{array}{c}-3.3 \mathrm{e}+08 \\
8.0 \\
1.6 \mathrm{e}+08\end{array}$ & $\begin{array}{c}-565.7 \\
8.0 \\
291.2\end{array}$ & $\begin{array}{c}-3.5 \mathrm{e}+08 \\
8.0 \\
1.7 \mathrm{e}+08\end{array}$ & $\begin{array}{c}-287.6 \\
8.0 \\
151.1\end{array}$ \\
\hline
\end{tabular}

Then the same procedure is applied to data for Turkey and as link function loglog is accepted depending on AIC and BIC criteria. Below is the result of all link functions for Turkey. Depending on Table 4 results of AIC and BIC, it appears that loglog model is the appropriate model to be selected for Turkey.

Table 4: AIC and BIC Values for Models (Turkey)

\begin{tabular}{llcc}
\hline Model & Df & AIC & BIC \\
\hline Blogit1 & 12 & -97.53 & -89.04 \\
Bprobit1 & 12 & -96.95 & -88.45 \\
Bcloglog1 & 12 & -97.59 & -89.09 \\
Bloglog1 & 12 & -96.39 & -87.90 \\
\hline
\end{tabular}

Table 5 shows the regression results for each model run for Turkey. On both tables for KSA and Turkey, the bold column indicates the chosen model for the related country. 
A. Polat $10 / 3(2018) 693-709$

Table 5: Beta Regression Models for Turkey

\begin{tabular}{|c|c|c|c|c|}
\hline & (1) logit & (2) probit & (3) cloglog & (4) loglog \\
\hline NPLs, \% ratio & NPLs, \% ratio & NPLs, $\%$ ratio & NPLs, $\%$ ratio & NPLs, \% ratio \\
\hline \multirow[t]{2}{*}{ GDP growth (annual \%) } & 0.021 & 0.008 & 0.021 & 0.005 \\
\hline & $(0.01)$ & $(0.01)$ & $(0.01)$ & $(0.00)$ \\
\hline \multirow[t]{2}{*}{ Inflation, CPI (annual \%) } & 0.022 & 0.011 & 0.021 & $0.008^{*}$ \\
\hline & $(0.01)$ & $(0.01)$ & $(0.01)$ & $(\mathbf{0 . 0 0})$ \\
\hline \multirow{2}{*}{$\begin{array}{l}\text { Unemployment, }(\% \text { of labor } \\
\text { force })\end{array}$} & 3.830 & 1.612 & 3.754 & 1.044 \\
\hline & $(7.81)$ & $(3.48)$ & (7.64) & (2.36) \\
\hline \multirow[t]{2}{*}{ Exchange Rates 1 USD to LCU } & -0.006 & -0.011 & -0.002 & -0.013 \\
\hline & $(0.55)$ & $(0.22)$ & $(0.55)$ & $(0.14)$ \\
\hline \multirow[t]{2}{*}{ Debt $\%$ of GDP } & 0.026 & 0.010 & 0.025 & 0.006 \\
\hline & $(0.03)$ & $(0.01)$ & $(0.03)$ & $(0.01)$ \\
\hline \multirow[t]{2}{*}{ Market CAP ( $\%$ of GDP) } & $0.022^{*}$ & $0.009^{*}$ & $0.021^{*}$ & $0.006^{*}$ \\
\hline & $(0.01)$ & $(0.00)$ & $(0.01)$ & $(0.00)$ \\
\hline \multirow[t]{2}{*}{ Transparency Int. CPI Index } & -0.004 & -0.003 & -0.004 & -0.002 \\
\hline & $(0.04)$ & $(0.02)$ & $(0.04)$ & $(0.01)$ \\
\hline \multirow[t]{2}{*}{ M3 Money Supply $2010=100$} & 0.002 & 0.001 & 0.002 & 0.001 \\
\hline & $(0.00)$ & $(0.00)$ & $(0.00)$ & $(0.00)$ \\
\hline \multirow{3}{*}{$\begin{array}{l}\text { Oil (EU Brent Spot FOB USD) } \\
\text { Price }\end{array}$} & -0.003 & -0.001 & -0.003 & -0.001 \\
\hline & & & & \\
\hline & $(0.01)$ & $(0.00)$ & $(0.01)$ & $(0.00)$ \\
\hline \multirow{2}{*}{$\begin{array}{l}\text { Dummy for crises of } 2001 \text { and } \\
2008\end{array}$} & $0.313^{*}$ & 0.129 & $0.310^{*}$ & 0.081 \\
\hline & $(0.16)$ & $(0.07)$ & $(0.15)$ & $(0.05)$ \\
\hline \multirow[t]{2}{*}{ constant } & $-6.115^{*}$ & $-2.944^{*}$ & $-6.105^{*}$ & $-1.909^{* * *}$ \\
\hline & $(2.81)$ & $(1.15)$ & $(2.78)$ & $(0.72)$ \\
\hline \multirow[t]{2}{*}{ constant } & $7.356^{* * *}$ & $7.317^{* * *}$ & $7.360^{* * * *}$ & $7.280^{* * * *}$ \\
\hline & $(0.37)$ & $(0.37)$ & $(0.37)$ & $(\mathbf{0 . 3 7})$ \\
\hline $\mathrm{BIC}$ & -89.0 & -88.5 & -89.1 & -87.9 \\
\hline $\mathrm{N}$ & 15.0 & 15.0 & 15.0 & 15.0 \\
\hline 11 & 60.8 & 60.5 & 60.8 & 60.2 \\
\hline
\end{tabular}

As indicated above, the original coefficients provided in the tables are not very useful and the margin command is required in order to compute average marginal effects. As the first dimension of the research focus on to find if there is any relation between NPLs and independent variables and the direction of the relation between dependent variable and independent variables and as the second dimension of the research question if the significant independent variables for NPLs ratio are same or different for the countries in our analysis, computing average marginal effects are not required at this step of the analysis. 
Table 6: Comparison of regression coefficients for Turkey and KSA

\begin{tabular}{|c|c|c|}
\hline NPLs, $\%$ ratio & $\begin{array}{c}\text { (1) logit } \\
\text { NPLs, \% ratio } \\
\text { KSA } \\
\end{array}$ & $\begin{array}{c}\text { (4) loglog } \\
\text { NPLs, \% ratio } \\
\text { TUR } \\
\end{array}$ \\
\hline GDP growth (annual \%) & $\begin{array}{c}0.326^{* * * *} \\
(0.00)\end{array}$ & \\
\hline Inflation, CPI (annual \%) & $\begin{array}{c}0.066^{* * * *} \\
(0.00)\end{array}$ & $\begin{array}{l}0.008^{*} \\
(0.00)\end{array}$ \\
\hline Unemployment, $(\%$ of labor force $)$ & $\begin{array}{c}-366.958^{* * * *} \\
(0.00)\end{array}$ & \\
\hline \multicolumn{3}{|l|}{ Exchange Rates 1USD to LCU } \\
\hline Debt $\%$ of GDP & $\begin{array}{c}0.012^{* * *} \\
(0.00)\end{array}$ & \\
\hline Market CAP ( $\%$ of GDP) & $\begin{array}{c}0.069^{* * * *} \\
(0.00)\end{array}$ & $\begin{array}{l}0.006^{*} \\
(0.00)\end{array}$ \\
\hline Transparency Int. CPI Index & $\begin{array}{c}-0.191^{* * *} \\
(0.00)\end{array}$ & \\
\hline M3 Money Supply 2010=100 & $\begin{array}{c}0.027^{* * *} \\
(0.00)\end{array}$ & \\
\hline \multicolumn{3}{|l|}{ Oil (EU Brent Spot FOB USD) Price } \\
\hline \multicolumn{3}{|l|}{ Dummy for crises of 2001 and 2008} \\
\hline constant & $\begin{array}{c}16.082^{* * *} \\
(0.00)\end{array}$ & $\begin{array}{c}-1.909^{* *} \\
(0.72)\end{array}$ \\
\hline $\mathrm{BIC}$ & $-3.3 e+08$ & -87.9 \\
\hline $\mathrm{N}$ & 8.0 & 15.0 \\
\hline 11 & $1.6 \mathrm{e}+08$ & 60.2 \\
\hline
\end{tabular}

The intuition behind this research is to analyze if macroeconomic determinants for NPLs ratio and their direction in effecting NPL is same or not for Turkey and Saudi Arabia.

\section{CONCLUSION}

This paper investigated the macroeconomic determinants of the NPLs ratio from 2000 to 2016 for Turkey and Saudi Arabia. Choosing these two countries is a timely preference due to structural changes in their economies. KSA is having a "saudization policy", the policy that Saudi companies and enterprises are required to fill up their workforce with Saudi nationals and such a scheme is going to have immense effects on the macroeconomic variables of the country. Turkey, having a devaluation in its currency due to local and international fluctuations based on mainly political and economic uncertainty in 2018, has the potential that NPLs can be influenced by the changing macroeconomic variables due to mainly increases in foreign exchange rate and country risk.

The initial assumption in the introduction of this paper was that the determinants for NPLs can be dissimilar for Saudi Arabia and Turkey depending on primarily country-specific factors. The results of our beta regression analysis confirms our primary assumption that the determinants of NPLs are different for the two countries.

Interpreting the results, the analysis shows that while GDP, inflation, debt, market capitalization and money supply has a positive effect in determining NPL for KSA, 
unemployment and transparency has a negative effect on it. So, if we change positive effect variables 1 unit, we would expect NPLs to increase by a unit of corrected coefficients after applying the margin command. Exchange rates, oil price and a dummy variable for the crises has no effect on NPL ratio for KSA.

It appears that there is a contagion channel between macroeconomic variables and NPLs ratio for KSA and NPLs can be easily affected by current value of its macroeconomic variables.

From the results for Turkey, it appears that only the current value of inflation and market capitalization of listed companies have a positive effect on NPLs. While results of analysis for KSA are easier to explain, the results of analysis for Turkey requires more elaboration. Turkey's current macroeconomic variables have little effect on determining current levels of NPLs ratio except inflation and market capitalization of listed companies. As it is known that Turkey has struggled in two different crisis and resilient banking sector has the ability to keep the NPLs ratio low with high-level credit management policies. That may be the result of the disconnection between many of the macroeconomic variables and NPLs ratio for Turkey for the current values. It appears from our results that increases in inflation in Turkey is a cause of increase in NPLs for Turkey. Therefore inflation rate is a collective transmission channel probably covering other macroeconomic effects in it. Another significant result for Turkey is market capitalization ratio. Increases of the market value of BIST companies outstanding shares as a percentage of GDP also increases the NPLs ratio. Although we do not have the breakdown of NPL data for BIST or non-BIST companies, the results shows that BIST companies also covers a part of NPLs in the banking system.

Another explanation for Turkey's macroeconomic data and NPLs disconnection can be lag effects. This research did not analyze if there is any lagged effect between independent variables and dependent variable. Therefore it is possible for Turkey that there may be a relation between NPL ratio of time $t$ and Independent Variables of time $\mathrm{t}-1$, or $\mathrm{t}-2$. For future analysis, the lag effect of macroeconomic variables on current NPLs needs investigation. Moreover, there may be other variables which are not included in our analysis that may be determining factors for NPLs.

\section{References}

Abdioğlu, N., \& Aytekin, S. (2016). Assessing the Factors that Impact Non-Performing Loan Ratio: An Application on Deposit Banks by Using Dynamic Panel Data. Journal of Business Research Turk, 8(1), 538-555.

Abid, L., Ouertani, M. N., \& Zouari-Ghorbel, S. (2014). Macroeconomic and Bankspecific Determinants of Household's Non-performing Loans in Tunisia: A Dynamic Panel Data. Procedia Economics and Finance, 13, 58-68. http://doi.org/10.1016/S2212-5671(14)00430-4

Ahmad, F. (2013). Corruption and Information Sharing as Determinants of NonPerforming Loans. Business Systems Research, 4(1), 87-98. http://doi.org/10.2478/bsrj-2013-0008

Ali, A., \& Daly, K. (2010). Macroeconomic determinants of credit risk: Recent evidence from a cross country study. International Review of Financial Analysis, 19(3), 165-171. 


\section{A. Polat $10 / 3(2018) 693-709$}

Ang, J. B. (2008). A survey of recent developments in the literature of finance and growth. Journal of Economic Surveys. http://doi.org/10.1111/j.14676419.2007.00542.x

Babouček, I., \& Jančar, M. (2005). Effects of macroeconomic shocks to the quality of the aggregate loan portfolio. Czech National Bank.

Badar, M., \& Yasmin Javid, A. (2013). Impact of macroeconomic forces on nonperforming loans: An empirical study of commercial banks in Pakistan. WSEAS Transactions on Business and Economics, 10(1), 40-48.

Baldini, A., \& Causi, M. (2018). Determinants Of Loan And Bad Loan Dynamics: Evidence From Italy.

Baum, C., Caglayan, M., \& Ozkan, N. (2002). The impact of macroeconomic uncertainty on bank lending behavior. Boston College WP, 1-13. Retrieved from http://www.econometricsociety.org/meetings/esem02/cdrom/papers/259/bankloans .pdf

Beck, R., Jakubik, P., \& Piloiu, A. (2015). Key determinants of non-performing loans: new evidence from a global sample. Open Economies Review, 26(3), 525-550.

Bofondi, M., \& Ropele, T. (2011). Macroeconomic determinants of bad loans: evidence from Italian banks. Bank of Italy (Vol. 89). Retrieved from www.bancaditalia.it/pubblicazioni/qef/2011-0089/QEF_89.pdf

Brownbridge, M. (1998). The causes of financial distress in local banks in Africa and implications for prudential policy. UNCTAD Discussion Papers, (March). http://doi.org/10.1111/1467-7679.00057

Calza, A., Gartner, C., \& Sousa, J. (2003). Modelling the demand for loans to the private sector in the euro area. Applied Economics, 35(1), 107-117. http://doi.org/10.1080/00036840210161837

Caprio, G., \& Klingebiel, D. (2002). Episodes of systemic and borderline banking crises. Managing the Real and Fiscal Effects of Banking Crises, World Bank Discussion Paper, 428, 31-49.

Ćurak, M., Pepur, S., \& Poposki, K. (2013). Determinants of non-performing loans-evidence from Southeastern banking systems. Banks \& Bank System, 8(1), 45-54.

De Gregorio, J., \& Guidotti, P. E. (1995). Financial development and economic growth. World Development. http://doi.org/10.1016/0305-750X(94)00132-I

Demetriades, P. O., \& Hussein, K. A. (1996). Does financial development cause economic growth? Time-series evidence from 16 countries. Journal of Development Economics. http://doi.org/10.1016/S0304-3878(96)00421-X

Demirguc-Kunt, A., \& Detragiache, E. (1998). The Determinants of Banking Crises in Developing and Developed Countries. IMF Staff Papers. http://doi.org/10.2307/3867330

Dimitrios, A., Helen, L., \& Mike, T. (2016). Determinants of non-performing loans: Evidence from Euro-area countries. Finance Research Letters, 18, 116-119. http://doi.org/10.1016/j.frl.2016.04.008

Dorta, M. (2016). Introduction to fractional outcome regression models using the 
fracreg and betareg commands. Retrieved from https://www.stata.com/meeting/mexico16/slides/Mexico16_Dorta.pdf

Espinoza, R., \& Prasad, A. (2010). Nonperforming Loans in the GCC Banking System and their Macroeconomic Effects. IMF Working Papers, 25. http://doi.org/10.5089/9781455208890.001

Ferrari, S. L. P., \& Cribari-Neto, F. (2004). Beta regression for modelling rates and proportions. Journal of Applied Statistics, 31(7), 799-815. http://doi.org/10.1080/0266476042000214501

Ghosh, A. (2015). Banking-industry specific and regional economic determinants of non-performing loans: Evidence from US states. Journal of Financial Stability, 20, 93-104. http://doi.org/10.1016/j.jfs.2015.08.004

González-Hermosillo, M. B. (1999). Determinants of ex-ante banking system distress: A macro-micro empirical exploration of some recent episodes. International Monetary Fund.

Hou, Y., \& Dickinson, D. (2007). The non-performing loans: some bank-level evidences. In 4th International Conference on Applied Financial Economics, Samos Island, Greece.

IMF. (2006). Spain: Financial Sector Assessment Program-Technical Note- Stress Testing Methodology and Results. Washington DC. Retrieved from https://www.imf.org/external/pubs/ft/scr/2006/cr06216.pdf

İslamoğlu, M. (2015). The effect of macroeconomic variables on non-performing loan ratio of publicly traded banks in Turkey. WSEAS Transactions on Business and Economics, 12, 10-20. http://doi.org/10.4038/suslj.v6i1.1689

Jakubík, P., \& Reininger, T. (2013). Determinants of Nonperforming Loans in Central, Eastern and Southeastern Europe. Focus on European Economic Integration, Q3, 48-66. http://doi.org/10.3326/fintp.38.1.2

Karabulut, G., \& Bilgin, M. H. (2011). Sources of non-performing loans in Turkish banking system. Journal of Business \& Economics Research (JBER), 5(10).

Keeton, W. R., \& Morris, C. S. (1987). Why do banks' loan losses differ? Economic Review, 72(5), 3-21.

Khemraj, T., \& Pasha, S. (2009). The determinants of non-performing loans: an econometric case study of Guyana. Munich Personal RePEc Archive, (53128), 125. http://doi.org/10.18488/journal.aefr/2015.5.6/102.6.868.882

Kimberly Beaton, Alla Myrvoda, and S. T. (2016). Non-Performing Loans in the ECCU : Determinants and Macroeconomic Impact. International Monetary Fund, 1-34. http://doi.org/10.5089/9781475555714.001

Klein, N. (2013). Non-Performing Loans in CESEE: Determinants and Impact on Macroeconomic Performance. IMF Working Papers, 13(72), 1. http://doi.org/10.5089/9781484318522.001

Louzis, D. P., Vouldis, A. T., \& Metaxas, V. L. (2012). Macroeconomic and bankspecific determinants of non-performing loans in Greece: A comparative study of mortgage, business and consumer loan portfolios. Journal of Banking \& Finance, 
36(4), 1012-1027.

Makri, V., Tsagkanos, A., \& Bellas, A. (2014). Determinants of non-performing loans: The case of Eurozone. Panoeconomicus, 61(2), 193.

Mashal, A. M. (2012). The Financial Crisis of 2008 - 2009 and the Arab States Economies. International Journal of Business and Management, 7, 96-111. http://doi.org/10.5539/ijbm.v7n4p96

Masood, O., \& Aktan, B. (2009). Determinants of non-performing loans: A comparative analysis. Actual Problems of Economics, (12), 251-263.

Masood, O., Bellalah, M., Mansour, W., \& Teulon, F. (2010). Non-Performing Loans and Credit Managers' Role: A Comparative Approach from Pakistan and Turkey. International Journal of Business, 15(3), 347-362. Retrieved from http://www.ipagcn.com/wpcontent/uploads/recherche/WP/IPAG_WP_2014_316.pdf

Messai, A. S., \& Jouini, F. (2013). Micro and Macro Determinants of Non-performing Loans. International Journal of Economics and Financial Issues, 3(4), 852-860. http://doi.org/10.1300/J079v27n04_02

Mileris, R. (2012). Macroeconomic Determinants of Loan Portfolio Credit Risk in Banks. Inzinerine Ekonomika-Engineering Economics, 23(5), 496-504. http://doi.org/10.5755/j01.ee.23.5.1890

Miyajima, K. (2017). What Influences Bank Lending in Saudi Arabia? (No. WP/17/31). Retrieved from https://papers.ssrn.com/sol3/papers.cfm?abstract_id=2938330

Murumba, I. (2013). The Relationship between Real GDP and Non-performing Loans: Evidence from Nigeria (1995 - 2009). International Journal of Capacity Building in Education and Management, 2(1), 1-7.

Ranjan, R., \& Dhal, S. C. (2003). Non-Performing Loans and Terms of Credit of Public Sector Banks in India: An Empirical Assessment. Reserve Bank of India Occasional Papers, 24(3), 81-121. http://doi.org/10.1080/08039410.1994.9665960

Saba, I., Kouser, R., \& Azeem, M. (2012). Determinants of Non Performing Loans: Case of US Banking Sector. The Romanian Economic Journal, 15(January), 141152.

Şahbaz, N., \& İnkaya, A. (2014). Türk Bankacılık Sektöründe Sorunlu Krediler ve Makro Ekonomik Etkileri. Optimum Journal of Economics and Management Sciences. Retrieved

from http://acikerisim.usak.edu.tr:8080/xmlui/handle/123456789/60

Saif-Alyousfi, A. Y. H., Saha, A., \& Md-Rus, R. (2018). Impact of oil and gas price shocks on the non-performing loans of banks in an oil and gas-rich economy: Evidence from Qatar. International Journal of Bank Marketing, 36(3), 529-556.

Siddiqui, S., Malik, K. S., \& Shah, S. Z. A. (2012). Impact of interest rate volatility on non-performing loans in Pakistan. International Research Journal of Finance and Economics, 84, 66.

Škarica, B. (2014). Determinants of non-performing loans in Central and Eastern European countries. Financial Theory and Practice, 38(1), 37-59. 
Smithson, M., \& Verkuilen, J. (2006). A better lemon squeezer? Maximum-likelihood regression with beta-distributed dependent variables. Psychological Methods, 11(1), 54-71. http://doi.org/10.1037/1082-989X.11.1.54

Stata. (2015). Stata Base Reference Manual Release 14 (14th ed.). Texas: Stata Press.

Tanasković, S., \& Jandrić, M. (2015). Macroeconomic and institutional determinants of non-performing loans. Journal of Central Banking Theory and Practice, 4(1), 4762. http://doi.org/10.1515/jcbtp-2015-0004

Tracey, M., \& Leon, H. (2011). The impact of non-performing loans on loan growth. IMF Working Papers.

Us, V. (2016). Determinants of Non-Performing Loans in the Turkish Banking Sector: What Has Changed After the Global Crisis? Research Notes in Economics, 2016(27).

Vatansever, M., \& Hepsen, A. (2015). Determining Impacts on Non-Performing Loan Ratio in Turkey. Journal of Applied Finance and Banking, 5(1), 1-11. Retrieved from http://www.scienpress.com/Upload/JFIA/Vol 2_4_7.pdf

von Peter, G. (2009). Asset prices and banking distress: A macroeconomic approach. Journal of Financial Stability, 5(3), 298-319. http://doi.org/10.1016/j.jfs.2009.01.001

Warue, B. N. (2013). The Effects of Bank Specific and Macroeconomic Factors on Nonperforming Loans in Commercial Banks in Kenya: A Comparative Panel Data Analysis. Advances in Management and Applied Economics, 3(2), 135-164. Retrieved from http://www.scienpress.com/Upload/AMAE\%2FVol 3_2_7.pdf

Yağcılar, G. G., \& Demir, S. (2015). Türk Bankacılık Sektöründe Takipteki Kredi Oranları Üzerinde Etkili Olan Faktörlerin Belirlenmesi. Uluslararast Alanya İsletme Fakültesi Dergisi, 7(1), 221-229.

Yang, L. (2003). The Asian financial crisis and non-performing loans: evidence from commercial banks in Taiwan. International Journal of Management, 20(1), 69.

Yücememiş, B. T., \& Sözer, İ. A. (2011). Bankalarda Takipteki Krediler: Türk Bankacılık Sektöründe Takipteki Kredilerin Tahminine Yönelik Bir Model Uygulaması. Finansal Araştırmalar ve Çalışmalar Dergisi, 3(5).

Zeng, S. (2012). Bank non-performing loans (NPLS): A dynamic model and analysis in China. Modern Economy, 3(01), 100.

\footnotetext{
${ }^{\mathrm{i}}$ According to BIS, the standard loan classifications are defined as 5 categories. Special Mention, Substandard, Doubtful, Virtual Loss and Loss(unrecoverable). NPLs are total of Substandard loans+Doubtfull+Virtifal loss and loss categories.
} 